\title{
Changes In the Trend of Communication In Interaction In the Digital Millennium
}

\author{
D A Firanti' ${ }^{1}$, Darmawan ${ }^{2}$, L Firdausah ${ }^{3}$, \\ ${ }^{1,2,3}$ Universitas Negeri Jakarta \\ 1 dindaayu_ikom19s1@mahasiswa.unj.ac.id, \\ ²bagasdarmawan_ikom19s1@mahasiswa.unj.ac.id, \\ 3latifahfirdausah_ikom19s1@mahasiswa.unj.ac.id
}

\begin{abstract}
Communication is a crucial thing that can affect the relationship between one human being and another human being. In his sense, communication is the process of interaction between two or more individuals whose purpose is to convey information. With the development of information technology, communication also changes media and delivery, and this can affect the attitude of individuals in interacting with others. The internet progress brought rapid change and created a new environmental transition that led the industrial society into a digital society. We use meta-analysis research methods with the type of literature study. This research uses two sources, namely primary and secondary sources. The results of the data are presented in the form of narrative texts, which are then analyzed with relevant theories to strengthen the results of our analysis, and the conclusions are also displayed in the narrative form. The results found that changes in communication trends occur due to technological developments and the development of new media in society. This paper will explain changes in communication trends, the development of communication information technologies, and the impact of technological advances on the millennium and digital communication alternatives.
\end{abstract}

Keyword: Communication, Change, Information Technology.

\section{INTRODUCTION}

The development of Information Technology has created new cultures and habits in society. Every human being digitally connected, high mobility, and all the ease of access makes everyone compete to compete and understand the latest technology. Communication is also more accessible with the presence of various social media, such as WhatsApp, Facebook, Twitter, Instagram, etc. the internet as a new medium at this time has become an important component of our daily lives and will become even more important in the future.

According to a report conducted by wearesocial.com, currently, $58 \%$ or 4.479 billion people in the world have accessed the internet. This number increased by $9.1 \%$ or 367 million from 2018. In other words, internet users are growing at a rate of more than 11 users per second. The way people use the internet is also growing rapidly. According to the data obtained, the average internet user spends 6 hours and 42 minutes online each day. That number dropped slightly in the previous year's figure of 6 hours and 49 minutes.

Especially in Indonesia, internet users have reached 150 million people or $56 \%$ of the total population of Indonesia. This figure is up $13 \%$ or by 17 million from last year. 
Indonesian people spend an average of 8 hours and 36 minutes online every day. Whatsapp is the most widely used digital communication media in Indonesia [1]. Indonesia called as one of the countries with the most internet users in the world.

The industrial revolution 4.0, which also increased the use of technology, created a new space called "Digital Society 4.0". Industry 4.0 is characterized by the digitalization and integration of industrial manufacturing and logistics processes, and the use of the internet and "smart" objects (machines and products) and combining the physical and virtual world by adopting information and communication technology (ICT). ) [2]. The current use of technology is not only limited to the field of communication but must also be added in the areas of politics, health, transportation, etc.

Actually, the development of technology is what is meant to have a positive effect on life, but unfortunately, the misuse of technology makes it seem as if the technology only has a negative impact. One of the things that resulted from the development of technology is the changing trend of communication between communities [3]. Social media has changed the way we communicate. Before the development of social media at the time like today, communication is done by face to face in person or by using letters sent by post. But nowadays, wherever we are, we can connect with others and interact with others. Connecting one person to another in the world through social media without distance is also called "death of distance."

The use of excessive social media can make someone experience dependency. Dependency Theory defines that dependence is related to efforts to meet the needs or achievement of goals by relying on other resources; in this case, social media [4]. The media is used as the only media to satisfy needs. As if human solah can no longer live without the media. So humans look for and do everything with the media. Its existence is considered a dominant social force. As Neil Postman revealed, that technology encourages technopoly culture which is a culture in which people worship technology and technology that controls all aspects of life [5].

In this paper, we examine how communication trends change in the era of digitalization, especially towards adolescents or millennials. We will also explain what the understanding of the millennial era is, why digital society can be formed, the causes of changes in communication trends in the millennial era, the impact of communication changes in the millennial era and alternatives to how people can use digital media but do not have a negative effect on themselves and people other. Finally, this paper was created to inform and educate readers about the changing trends of communication in the millennial era.

\section{RESEARCH METHOD}

In this paper, we use meta-analysis research methods which is an integrative analysis of the result of analyses of studies with the same focus or theme. [6] In this paper data collection techniques use journals and books as the source of the data. Because our research uses the meta-analysis method, we have two sources of data, namely primary data as primary data and secondary data as supporting data in our paper. The primary data we use are sourced from events that occur in everyday life, while the secondary data that we use are sourced from journals and books. The results of the data presented are in the form of narrative texts which are then analyzed with relevant theories to strengthen the results of our analysis, and the conclusions are also displayed in narrative form. Several source from journals and books that we use for this paper : 
1. L.M . Fonseca, "ndustry 4.0 and digital society: concepts, dimensions, and envisioned benefits," p.3, 2018

2. N.A. Ali, Laman Media Sosial; Trend Komunikasi Masa Kini, Malaysia, 2012

3. A. Schrock, "Myspace Or Ourspace: A Media System Denpendency View Of Myspace," University of Central Florida, p.4 2006

4. R. L. L. D. Joseph Staubhaar, Media Now: Understanding Media, Culture, and Technology, $7^{\text {th }}$ edition, Wadsworth, 2010.

5. D. S. Lynne C Lancaster, When Generations Collide: Who they are. Why They Clash. How to Solve the Generational Puzzle at Work, New York: HarperCollins, 2013.

6. Dr. H. Abd Rasyid M., Perubahan Sosial dan Strategi Komunikasi (Efektifitas Dakwah dalam Pembangunan Sosial), Jawa Timur: Wade Group, 2018.

7. E. M. Rogers, Communication Technology: The New Media in Society, New York, 1986.

8. S. F. Soliha, "Tingkat Ketergantungan Pengguna Media Sosial dan Kecemasan Sosial," Jurnal Interaksi, vol.4, no.1, p.6, 2015.

9. Y. A. Piliang "Masyarakat Informasi dan Digital: Teknologi Informasi dan Perubahan Sosial", Jurnal Sosioteknologi Institut Teknologi Bandung, vol.11, no.27, p. $152,2012$.

10. S.KEMP, "wearesocial.com" , 23 October 2019, https://wearesocial.com/blog/2019/10/the-global-state-of-digital-in-october-2019. (Accessed 10 November 2019

11. M.S. JAMIL, "hipe.id" , 11 July 2019, https://blog.hype.id/bagaimana-preferensikomunikasi-generasi-millenial-dalam-dunia-kerja/. (Accessed 18 November 2019)

12. F.NEWPORT, "Gallup.com" , 10 November 2014, https://news.gallup.com/poll/179288/new-era-communication-americans.aspx. (Accessed 18 November 2019)

13. Y.A.Piliang, "MASYARAKAT INFORMASI DAN DIGITAL: Teknologi Informasi dan Perubahan Sosial" , Jurnal Sosioteknologi Institut Teknologi Bandung”, vol.11, no.27, p.152: 2012

14. Kadir, "META-ANALYSIS OF THE EFFECT OF LEARNING INTERVENTION TOWARD MATHEMATICAL THINKING ON RESEARCH AND PUBLICATION OF STUDENTS", Journal of Education in Muslim Society, vol.4, no.2, p. $165: 2017$

15. Adib, Mohammad. (2011). Filsafat ilmu: onto-logi, epistemologi, aksiologi, dan logika ilmu pengetahuan. Yogyakarta: Pustaka Pelajar.

\section{RESULTS AND DISCUSSION}

The millennial generation is different from the previous generation, this millennial generation is not only advanced and superior in the field of science, social politics but this millennial generation is also superior in the field of technology because of the technology that was developing very rapidly at that time Millennial is a cohort term in demographics, noun meaning followers or groups.

Currently, there are four major cohorts in demographics, namely Baby Boomers (born 1946 - 1964), Gen-X (born 1965 - 1980), Millennial (born 1981-2000), and Gen-Z (born in 2001-present). In other literature, According to Absher and Amidjaya that the millennial generation is the generation born between 1982 and 2002, the difference is not too significant 
(Ali \& Lilik Purwandi, 2017). The millennial generation is a modern generation living at the turn of the millennium.

According to Yuswohady, in the article Milennial Trends (2016) [7], Millennial generation (Millennial Generation) is a generation born at the beginning of the year 1980 to 2000. This generation is frequent, also known as Gen-Y, Net Generation, Generation WE, Boomerang Generation, Peter Pan Generation, and others. They called millennial generation because they are a generation that lives at the turn of the millennium. Simultaneously in this era of digital technology began to penetrate all the joints of life.

Based on research results from Lancaster \& Stillman (2002) [8], Generation Y known as the millennial generation or millennium. The phrase Generation $\mathrm{Y}$ begins used in the editorials of major American newspapers States in August 1993. This generation many use communication technology instants like electronic mail or email, social media like Facebook, Instagram, Twitter, and many more, In other words, Generation $\mathrm{Y}$ is a generation that grew up in the booming internet era.

From this definition, the millennial generation is the generation born between 1980-2000 when technological advances occurred rapidly. With the very rapid development of technology at that time was the generation that was greatly influenced by the technology, and the technology that entered gave many effects to that generation. If seen from the age group, Millennial generation is a generation currently around 15-34 years old.

Social change is experienced by every society that is essentially inseparable with cultural change, the community concerned [9]. Such as changes in work, communication, attitudes, and others. Many positive things are obtained in this millennial era as in work. The positive thing in the scope of work is when doing activities at the same time or multi-tasking is one of the advantages possessed by the millennial generation.

Changes in community attitudes that occur in the millennial era at this time are very changing; a lot of attitudes of concern for others that have begun to disappear. Besides, in the field of technology, work also has a good effect on communication, as in the case of sending long-distance messages in the millennial era, this can be done not only via voice but can also be done with video calls. This makes it easier for individuals who must be separated by family, friends, and spouses.

The form of communication trends is based on what technology is developing in society. Everett M. Rogers [10] defines that communication technology is the hardware in an organizational structure that contains a social value that allows everyone to collect, process, and exchange information with others. As a technology, rogers [10] further said that communication technology conditions its users to demassify message control, adjust to technical standards of use, and increase interaction between individuals without knowing the distance. It is undeniable that currently, communication technology is developing very fast. It happens because the community has entered the concept of a digital society in which all aspects of people's lives depend on technology.

In this millennial era, technology is very dominant. In the beginning, technology developed slowly. But along with advances in the level of culture and human civilization technological development is developing rapidly. The more advanced the culture, the more developed the technology because technology is the development of a rapidly advancing culture [11] .Communication that initially uses face-to-face communication turns into communication using the internet and smartphone media [12]. Social media, including instant messaging, is a superior tool for communicating and exchanging information with others. Even $68 \%$ of millennials claim to send very many messages regularly every day through this social media [13]. As we often see in everyday life where the majority of people always use 
their smartphones all the time, such as in public places, transportation, schools, and even when gathering with friends.

Social media has a solid relationship with social anxiety and dependence [14]. Someone who has high social anxiety and has a social condition disorder will encourage himself to use social media and actively interact virtually in cyberspace. This can create the formation of two identities between the real world and the virtual world, and this is what will make a person experience dependence and survive in his virtual world [15]. Also, the development of social media causes hoax news to rise in the community. According to the Indonesian Telecommunications Society survey agency said that $92.4 \%$ of the hoax found in the community came from social media.

Also, the change in the way of communication from direct communication to indirect communication causes frequent misunderstanding in conversation, misuse of punctuation and typing errors are often the main factors of the misunderstanding. One example is "you made a mistake" with "you made a mistake?" Both sentences could change meaning if the person who sent the message forgot to use punctuation. Many things are also ambiguous in indirect communication, such as the use of inappropriate emojis and others.

The problem of communication through digital media and the use of social media must be overcome. We certainly cannot stop using digital media, but we must limit ourselves in the use of digital media. We can concern ourselves with activities in the community, interact with others, and add insight. Apart from users, the government and platform providers should pay attention to the effects. They should have taken care to ensure that everything that is in the community is not just used just like that but is beneficial and does not interfere with the social life of the community.

\section{CONCLUSIONS}

This research found today's society is very suitable and collects all that is digital. Because the initial purpose of digitizing is good, if we as users do not use it wisely, it will have a bad impact on us. Millennial society, as the successor to the nation, can be wiser in doing something. Communication is a crucial thing that can affect the relationship of one human with another human being considered a serious thing. We do not need to rely on instant messages or social media in relationships that have many things that can occur in the delivery of his message. We must be able to master the technology, not to the technology that controls us.[1]

\section{REFERENCES}

[1] S. KEMP, “wearesocial.com," 23 October 2019. [Online]. Available: https://wearesocial.com/blog/2019/10/the-global-state-of-digital-in-october-2019. [Diakses 10 November 2019].

[2] L. M. Fonseca, "ndustry 4.0 and the digital society: concepts, dimensions and envisioned benefits," p. 3, 2018.

[3] N. A. Ali, Laman Media Sosial; Trend Komunikasi Masa Kini, Malaysia, 2012.

[4] A. Schrock, "Myspace Or Ourspace: A Media System Dependency View Of Myspace," University Of Central Florida, p. 4, 2006.

[5] R. L. L. D. Joseph Straubhaar, Media Now: Understanding Media, Culture, and Technology, 7th edition, Wadsworth, 2010. 
[6] Kadir, "meta-analysis of the effect of learning intervention toward mathematical thinking on research and publications on students," journal of education in muslim society, p. 165, 2917.

[7] Yuswohady, "Yuswohady," 15 October 2016. [Online]. Available: https://www.yuswohady.com/2016/. [Diakses 16 November 2019].

[8] D. S. Lynne C Lancaster, When Generations Collide: Who They Are. Why They Clash. How to Solve the Generational Puzzle at Work, New York: HarperCollins, 2013.

[9] S. M. M. M. Dr. H. Abd Rasyid M., Perubahan Sosial dan Strategi Komunikasi ( Efektiftas Dakwah Dalam Pembangunan Sosial), Jawa Timur: Wade Group, 2018.

[10] E. M. Rogers, Communication Technology: The New Media in Society, New York, 1986.

[11] M. Adib, Filsafat ilmu: onto-logi, epistemologi, aksiologi, dan logika ilmu pengetahuan., Yogyakarta: Pustaka Pelajar, 2011.

[12] M. S. JAMIL, "hipe.id," 11 July 2019. [Online]. Available: https://blog.hipe.id/bagaimana-preferensi-komunikasi-generasi-milenial-dalam-duniakerja/. [Diakses 18 November 2019].

[13] F. NEWPORT, “Gallup.com," 10 November 2014. [Online]. Available: https://news.gallup.com/poll/179288/new-era-communication-americans.aspx. [Diakses 18 November 2019].

[14] S. F. Soliha, "TINGKAT KETERGANTUNGAN PENGGUNA MEDIA SOSIAL DAN KECEMASAN SOSIAL,” JURNAL INTERAKSI, vol. 4, no. 1, p. 6, 2015.

[15] Y. A. Piliang, "MASYARAKAT INFORMASI DAN DIGITAL: Teknologi Informasi dan Perubahan Sosial," Jurnal Sosioteknologi Institut Teknologi Bandung, vol. 11, no. 27, p. 152, 2012. 